\title{
PERILAKU KEWIRAUSAHAAN PADA USAHA MIKRO KECIL (UMK) TEMPE DI BOGOR JAWA BARAT
}

\author{
Tita Nursiah ${ }^{1}$, Nunung Kusnadi ${ }^{2}$, dan Burhanuddin ${ }^{2}$ \\ 1)Mahasiswa Pascasarjana Magister Sains Agribisnis, Departemen Agribisnis \\ Fakultas Ekonomi dan Manajemen, Institut Pertanian Bogor \\ 2)Staf Pengajar Departemen Agribisnis, Fakultas Ekonomi dan Manajemen, Institut Pertanian Bogor \\ e-mail : 1)nursiahtita@gmail.com
}

\begin{abstract}
Micro and small enterprises (MSE) is a dominant business form in Indonesia with the percentage up to $90 \%$. However, there is a tendency that the entrepreneur is identified to large scale of business. The purpose of this study were (1) identify the characteristics of entrepreneurs in MSE industry (2) analyze the effect of entrepreneurial characteristics and the business climate for entrepreneurial behavior (3) analyze the effect of entrepreneurial behavior on its performance. Purposive sampling technique was applied to select 121 respondent. Structural Equation Modelling (SEM) was used to estimate entrepreneurial behavior. The results of this study showed that entrepreneurial characteristics was found on the MSE, furthermore stronger entrepreneurial characteristics was found on the large scale production. There is a positive and significant relationship between entrepreneurial characteristics and the business climate for entrepreneurial behavior. Entrepreneurial characteristics was influencing the most on the behavior of entrepreneurs. In addition entrepreneurial behavior was also positive and significant influence on its business performance. Thus, this study confirmed that entrepreneurial behavior was also found in small businesses, not only in large enterprises.
\end{abstract}

Keywords: small micro enterprises (MSEs), structural equation models, tempe industry.

\section{PENDAHULUAN}

Wirausaha diyakini sebagai roda penggerak pertumbuhan ekonomi, serta wirausaha juga dianggap sebagai inovator dalam pengembangan ekonomi. Tingginya persentase jumlah wirausaha di suatu negara maka perekonomian negara tersebut akan tumbuh dengan baik (Casson et al, 2006). Jumlah wirausaha Indonesia pada tahun 2013 mencapai 1,90 persen dari seluruh jumlah penduduk di Indonesia. Persentase tersebut masih sangat kecil dibandingkan negara Asia lainnya, seperti Cina dan Jepang, yang memiliki wirausaha lebih dari 10 persen dari jumlah populasi penduduk. Di regional Asia Tenggara, Indonesia masih di bawah Malaysia yang sudah mencapai angka (5\%) atau Singapura (7\%) (Kemenkop, 2012).
Pelaku usaha di Indonesia sebagian besar didominasi oleh UMKM. Jumlah UMKM di Indonesia mencapai 56 juta unit usaha. Namun demikian, pemilik usaha ini tidak dihitung sebagai wirausaha sesuai dengan penilaian Kemenkop. Mengacu pada definisi wirausaha adalah perorangan yang memiliki kemampuan untuk menciptakan sesuatu, dengan bekerja sendiri, mampu menghadapi risiko dengan memanfaatkan peluang yang ada (Casson, 2006). Pada kenyataannya UMKM tersebut memiliki peranan yang penting bagi negara yaitu penyerapan tenaga kerja dan penyumbang PDB. Peran dan eksistensi UMKM dalam penyerapan tenaga kerja dan kontribusinya terhadap Produk Domestik Bruto (PDB) Nasional sudah tidak diragukan lagi. Jumlah wirausaha UMKM dapat dilihat pada Tabel 1. 
Tabel 1. Perkembangan Jumlah Usaha UMKM dan Besar, PDB RI Tahun 2010-2012

\begin{tabular}{|c|c|c|c|c|c|}
\hline Indikator & $\begin{array}{c}2010 \\
\text { Jml unit }\end{array}$ & $\begin{array}{c}2011^{*} \\
\text { Jml unit }\end{array}$ & $\begin{array}{c}\text { PDB } \\
(\%)\end{array}$ & $\begin{array}{c}2012^{*} \\
\text { Jml unit }\end{array}$ & $\begin{array}{c}\text { PDB } \\
(\%)\end{array}$ \\
\hline Unit usaha & $53,828,569$ & $55,211,396$ & & $56,539,560$ & \\
\hline UMKM & $53,823,732$ & $55,206,444$ & 50.04 & $56,534,592$ & 54.77 \\
\hline Usaha besar & 4,837 & 4,952 & 49.96 & 4,968 & 45.23 \\
\hline
\end{tabular}

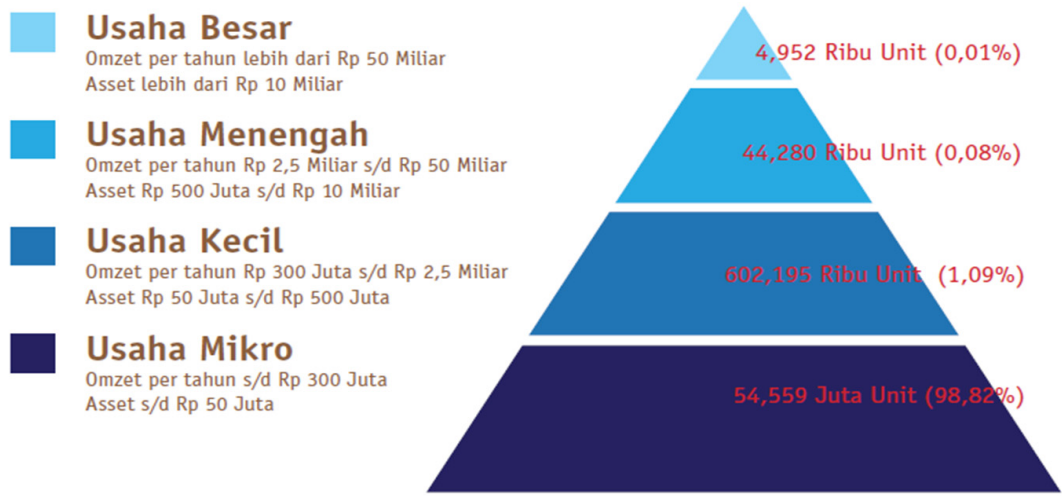

Gambar 1. Persentase Jumlah UMKM di Indonesia Tahun 2012

Berdasarkan (Gambar 1) jumlah total UMKM yang ada, 90 persennya didominasi oleh usaha mikro dan kecil. Pemberdayaan Usaha Mikro Kecil (UMK) menjadi sangat strategis, karena potensinya yang besar dalam menggerakkan kegiatan ekonomi masyarakat, serta menjadi tumpuan sumber pendapatan untuk meningkatkan kesejahteraan masyarakat. Menurut penelitian Bosma (2011), tren munculnya wirausaha adalah karena tekanan ekonomi, sehingga seseorang terpaksa menciptakan lapangan pekerjaan sendiri. Selain itu ada faktor lain yaitu pengangguran, frustasi pekerjaan sebelumnya, dan kebutuhan hidup layak (Mazzarol et al., 1999; Shane et al (2003); Segal, et al (2005). Dikarenakan latar belakang tersebut tidak heran banyak usaha-usaha mikro dan kecil yang bermunculan, namun tidak dapat berkembang menjadi usaha besar. Fenomena tersebut banyak terjadi di Indonesia salah satunya adalah UMK. Fugate et al (2005), menyatakan bahwa usaha mikro merupakan salah satu teknik kewirausahaan untuk mempromosikan ekonomi swasembada yang memungkinkan pelaku usaha mikro dapat menciptakan lapangan kerja sendiri dan memiliki pendapatan dengan menggunakan metode bottom-up. Penggolongan usaha mikro menurut Fugate et al adalah pedagang kaki lima, pengrajin kecil, pemilik toko kecil, dan pedagang kecil.

Salah satu jenis Usaha Mikro Kecil (UMK) yang berkembang adalah usaha pembuatan tempe. Di Indonesia tempe dikenal sebagai makanan khas asli Indonesia. Pelaku usaha ini pun tersebar di wilayah Jawa Barat salah satunya di Bogor. Pelaku usaha ini sebagian besar didominasi oleh para pendatang yang berasal dari Pekalongan Jawa Tengah. Usaha ini memiliki karakteristik yang unik, suplai bahan baku usaha pembuatan tempe $100 \%$ diperoleh dari kedelai impor. Dengan demikian, adanya perubahan harga kedelai akan berpengaruh langsung terhadap perkembangan usaha serta perilaku pengrajin dalam menyiasati keadaan tersebut. Usaha ini sebagian besar masih bersifat turun temurun, tradisional, serta dengan skala usaha rumah tangga. Namun demikian, meskipun usaha ini terkendala dengan harga bahan baku serta modal, para pelaku usaha tetap bertahan mengusahakan hingga bertahun-tahun 
meskipun perkembangan usaha tersebut tidak signifikan.

Oleh karena itu, perilaku tersebut di atas menjadi dasar yang melatarbelakangi dari penelitian perilaku kewirausahaan pada UMK ini. Penelitian ini difokuskan pada perilaku kewirausahaan pada UMK dikarenakan adanya sifat dan ciri yang unik dari UMK yang tidak dimiliki oleh usaha besar. Sulitnya bahan baku, kenaikan harga bahan baku, tidak adanya tempat yang layak untuk membuka usaha, serta keterbatasan modal tidak menjadi penghalang usaha ini tetap berjalan. Ciri lain UMK adalah lemah dalam perencanaan, lemah dalam bekerja sama dengan individu lain baik pemasok, pemodal, maupun dengan pengusaha lain, serta pengusaha mikro belum dapat memposisikan diri sebagai pengusaha yang berkualitas dan subsisten (Riyanti, 2006). Namun demikian, pelaku UMK mampu bertahan menjalankan usaha hingga bertahun-tahun meskipun tidak diikuti oleh perkembangan usaha yang signifikan. Namun demikian pelaku usaha ini belum semuanya dikategorikan sebagai wirausaha. Oleh karena itu pada penelitian ini juga ingin menganalisis bagaimana karakteristik wirausaha pada UMK tempe. Tujuan dari penelitian ini adalah :

1. Mengidentifikasi karakteristik dan ciri wirausaha pada UMK

2. Menganalisis pengaruh faktor karakteristik wirausaha (internal factor) dan iklim bisnis (external factor) terhadap perilaku kewirausahaan pada UMK,

3. Menganalisis pengaruh perilaku kewirausahaan UMK terhadap kinerja usaha.

\section{METODE}

\section{LOKASI DAN WAKTU PENELITIAN}

Penelitian dilakukan pada bulan Desember 2014 sampai Februari 2015 di wilayah Bogor, Jawa Barat. Lokasi penelitian dipilih secara sengaja (purposive) dengan pertimbangan bahwa di Bogor terdapat jumlah IKM terbesar ketiga se-Jawa Barat dengan jumlah 22.337 unit. Pemilihan industri tempe untuk diteliti dikarenakan ada karakteristik yang unik pada usaha ini. Keunikan usaha ini adalah tempe merupakan makanan khas asli Indonesia yang banyak diminati masyarakat dari kalangan bawah hingga atas. Selain itu industri ini sebagian besar berskala kecil, turun temurun, dengan teknologi yang masih sederhana dan terkendala oleh bahan baku. Keterbatasan bahan baku dalam negeri sehingga mengharuskan impor. Adanya kenaikan harga kedelai yang terus meningkat menjadi salah satu kendala yang besar dalam usaha ini, tetapi industri ini masih mampu bertahan. Selain itu juga dikarenakan terdapat beberapa sentra industri pembuatan tempe yang berkembang di Bogor menurut data dari KOPTI Bogor tahun 2012 yaitu di Citereup, Cimanggu, Cilendek, Cibinong, dan Ciseeng.

\section{JENIS DAN SUMBER DATA}

Jenis data yang digunakan dalam penelitian ini adalah data primer dan sekunder. Perolehan data primer dilakukan dengan wawancara langsung dengan bantuan kuesioner. Sementara data sekunder diperoleh dari berbagai instansi terkait, seperti Kementerian Koperasi dan UKM, Badan Pusat Statistik, Pemprov Jabar, serta Kopti Bogor.

\section{METODE PENENTUAN SAMPEL}

Pengambilan sampel dilakukan dengan teknik purposive sampling dengan sampel 121 orang pengrajin tempe. Penghitungan ini didasarkan karena pada penelitian ini menggunakan alat analisis SEM sehingga ukuran sampel yang digunakan harus dalam jumlah yang besar. Jumlah sampel yang diambil banyak dikarenakan agar hasil analisis yang diperoleh dapat mendekati dan menggambarkan faktor-faktor yang mempengaruhi perilaku kewirausahaan pada pengrajin tempe yang ada di Bogor. 


\section{METODE PENGOLAHAN DAN ANALISIS DATA}

Data diolah secara kualitatif maupun kuantitatif. Data kualitatif diolah secara deskriptif dengan bantuan Microsoft excel 2007. Data yang diolah adalah karakteristik dan ciri wirausaha UMK. Sementara data kuantitatif diolah dengan menggunakan analisis Structural Equation Models (SEM) dengan bantuan software Lisrel 8.3.

Alasan penggunaan model SEM pada penelitian ini, karena SEM mampu memberikan informasi tentang hubungan kausal simultan antar variabel serta informasi mengenai muatan faktor dan kesalahan pengukuran. Selain itu SEM juga mampu menunjukkan konsep-konsep yang tidak teramati (unobserved concepts) serta hubungan yang ada di dalamnya

Terdapat beberapa tahapan dalam penggunaan SEM menurut Bollen dan Long 1993 (Wijanto, 2008), yaitu : (1) Spesifikasi model (model specification), (2) Identifikasi (Identification), (3) Estimasi (Estimation), (4) Uji kecocokan (Testing Fit), (5) Respesifikasi (Respecification). Berikut adalah model yang digunakan pada penelitian ini dapat dilihat pada Gambar 2. Sementara variabel yang digunakan pada penelitian ini dapat dilihat pada Tabel 2

Tabel 2. Variabel Penelitian Perilaku Kewirausahaan pada UMK Tempe

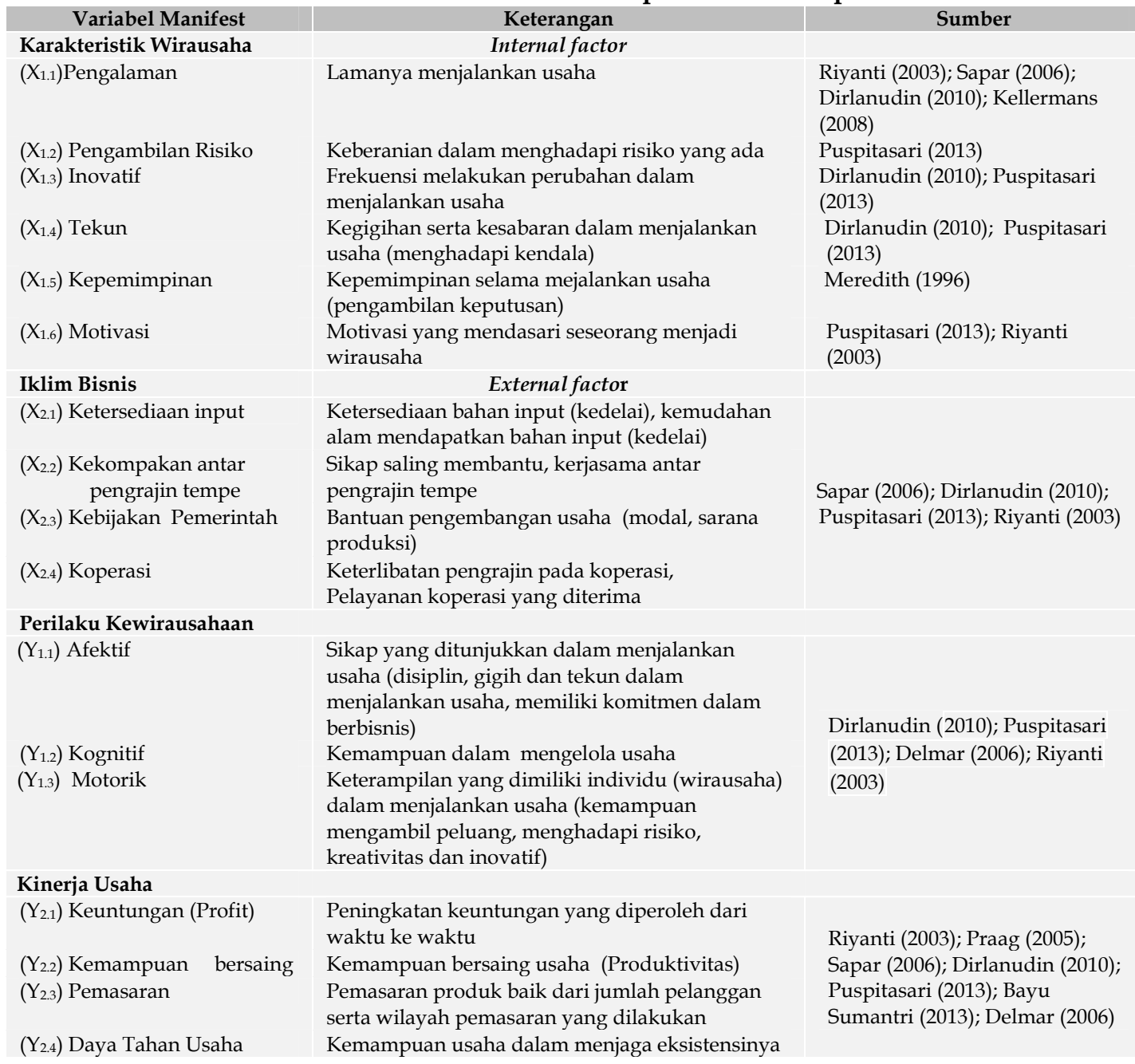




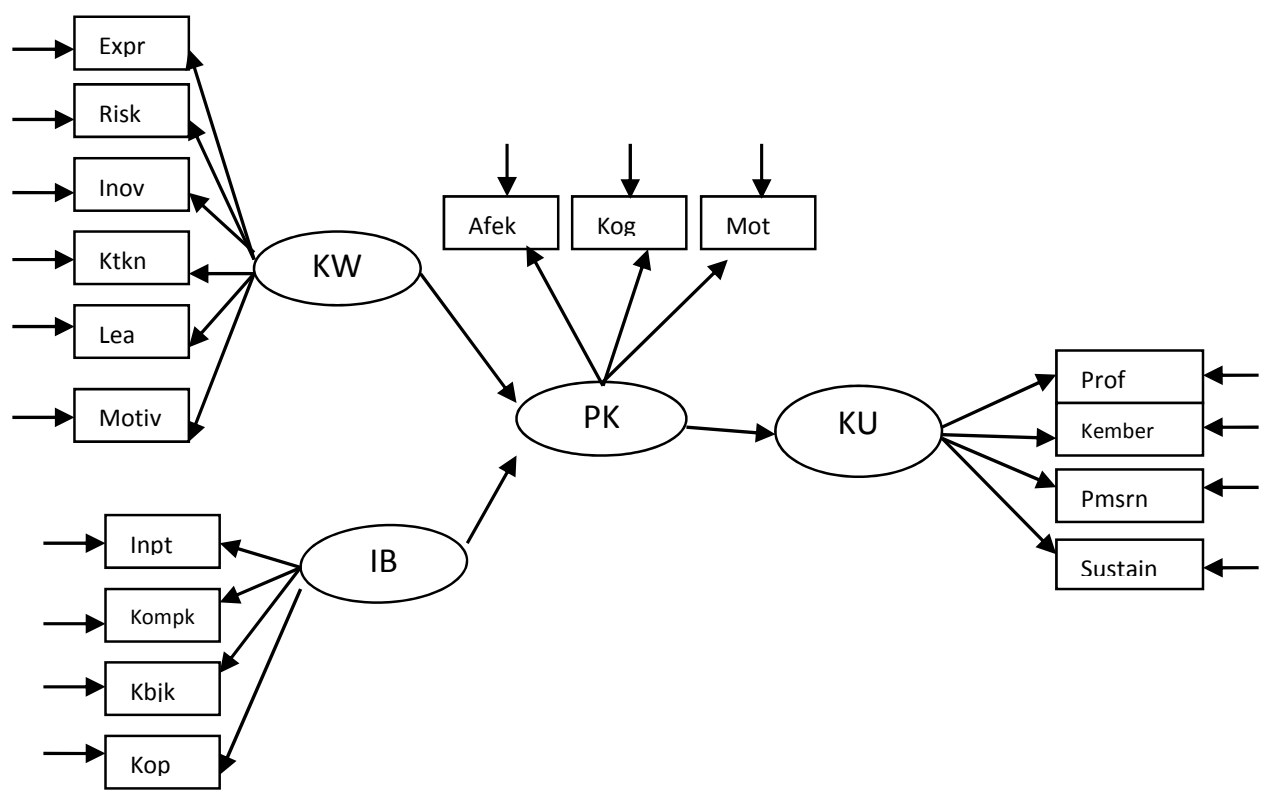

Gambar 1. Model Perilaku Kewirausahaan pada UMK Tempe di Bogor

\section{HASIL DAN PEMBAHASAN}

\section{KARAKTERISTIK WIRAUSAHA USAHA MIKRO KECIL PADA PENGRAJIN TEMPE}

Analisis karakteristik wirausaha diperoleh dari penghitungan hasil wawancara dengan bantuan penilaian likert. Analisis ini didasarkan pada enam variabel (pengalaman, inovasi, pengambilan risiko, ketekunan, kepemimpinan, dan motivasi) dikarenakan seorang wirausaha memiliki karakteristik atau ciri inovatif, berjiwa pemimpin, berani mengambil risiko, memiliki motivasi, serta tekun, dan berpengalaman (Meredith 1996, Alma 2010, Casson 2006, Puspita 2013). Nilainilai dari keenam variabel tersebut yang dijadikan sebagai ukuran pengelompokkan responden memiliki karakter wirausaha tinggi, rendah, dan sedang. Untuk melihat karakteristik wirausaha pada usaha tempe, dilakukan pengelompokan menjadi tiga skala usaha yang didasarkan pada jumlah produksi. Jumlah produksi kurang dari $50 \mathrm{~kg}$ dikategorikan sebagai skala kecil, 51-100 kg sebagai skala sedang, dan lebih dari $100 \mathrm{~kg}$ sebagai skala besar. Berikut adalah sebaran responden berdasarkan karakteristik wirausaha dapat dilihat pada Gambar 2.
Berdasarkan dari hasil analisis, diperoleh hasil bahwa responden dengan karakteristik wirausaha yang tinggi paling banyak (71\%) tersebar pada skala usaha besar. Sementara pada skala usaha kecil sebaran responden paling banyak dengan karakteristik wirausaha yang rendah (49\%). Dengan demikian, hal ini menunjukkan bahwa seorang wirausaha yang sukses memiliki karakteristik wirausaha yang kuat untuk menunjang keberhasilan usaha. Seseorang yang dikategorikan sebagai wirausaha harus memiliki karakteristik yang menunjukkan ciri seorang wirausaha. Beberapa karakter yang dapat mewakili adalah inovatif, berani mengambil risiko, kepemimpinan, motivasi, serta ketekunan dan pengalaman.

Berdasarkan sebaran tersebut, dapat menjelaskan bagaimana karakter wirausaha pada pengrajin tempe. Dengan jumlah responden yang diambil sebanyak 121 orang, jumlah responden pada skala usaha kecil sebanyak 63 orang $(52 \%)$, skala sedang sebanyak 51 orang $(42 \%)$, dan skala besar sebanyak 7 orang (6\%). Berdasarkan jumlah tersebut sebagian besar pengrajin tempe di Bogor memiliki karakteristik wirausaha yang masih rendah. 


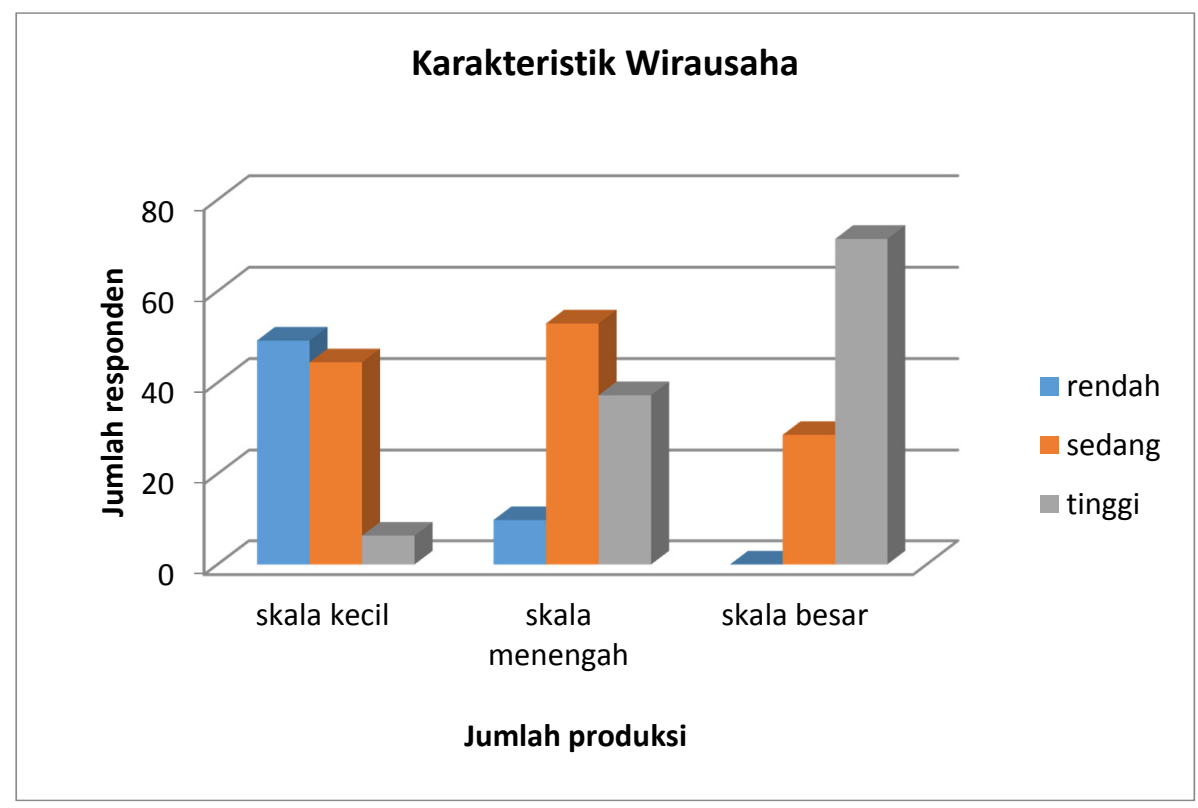

Gambar 2. Sebaran Responden Berdasarkan Karakteristik Wirausaha (\%)

Karakteristik wirausaha ini akan mempengaruhi perilaku wirausaha dalam menjalankan usahanya. Sebagian besar dari responden adalah pengrajin dengan skala usaha kecil dan hanya sedikit yang mampu menjalankan usaha pada skala besar. Hal ini juga tidak hanya dipengaruhi oleh karakter kuat wirausaha yang dimiliki individu, tetapi juga dipengaruhi oleh lingkungan yang akan membentuk perilaku wirausaha yang dilakukan selama menjalankan usahanya.

Menurut Nedler (Dirlanudin 2010), menyatakan bahwa perilaku adalah fungsi dari interaksi antara individu dengan lingkungannya. Hal ini dapat disimpulkan bahwa seorang individu dengan lingkungan akan membentuk perilaku secara langsung, baik perilaku dalam berwirausaha atau bisnis. Begitu juga dengan perilaku kewirausahaan pada pengrajin tempe, yang juga dipengaruhi dari keinginan individu sendiri dan didukung oleh lingkungan. Perilaku pengrajin tempe yang memiliki karakteristik wirausaha kuat lebih memiliki motivasi kuat dalam menjalankan usaha, tidak hanya ingin usahanya berjalan lancar apa adanya tapi menginginkan usahanya berkembang dan dapat berproduksi dengan skala yang lebih besar.
Wirausaha ini lebih berani dalam mengambil risiko serta memiliki strategi yang dijalankan agar usahanya berkembang. Pengambilan risiko yang diambil seperti memproduksi tempe yang lebih banyak meskipun harga kedelai meningkat, wirausaha ini tidak takut tempe yang diproduksinya tidak laku. Selain itu wirausaha ini aktif mencari pasar baru untuk meluaskan wilayah pemasaran. Keberanian seseorang dalam mengambil risiko didukung oleh pengetahuan, pengalaman, kekuatan modal, serta kemampuan dalam menanggapi perubahan atau mengambil peluang, serta kreatif dan inovatif. Holt dan Drucker (Riyanti, 2003) menyatakan pentingnya sebuah inovasi dan menegaskan bahwa keberhasilan seorang wirausaha adalah harus memiliki karakter kreatif dan inovatif. Kreativitas adalah menghasilkan ide atau gagasan baru tanpa harus merealisasikan gagasan tersebut atau merupakan prasyarat inovasi, sedangkan inovasi adalah aplikasi dari gagasan-gagasan kreatif. Suatu gagasan baru memiliki nilai bila gagasan tersebut dapat diterapkan pada suatu produk.

Sementara untuk pengrajin tempe yang memiliki karakteristik wirausaha rendah, tidak berani dalam mengambil risiko. 
Terbukti dengan adanya pengrajin yang memproduksi tempe dengan jumlah yang sama dari awal membuka usaha hingga sekarang dengan jumlah yang sangat kecil yaitu kurang dari $50 \mathrm{~kg}$. Para pengrajin ini pun puas dengan penghasilan yang diperoleh sehingga tidak ada motivasi untuk meningkatkan volume usahanya, sehingga hanya berorientasi pada pemenuhan kebutuhan keluarga saja. Hal ini juga didukung oleh Wirasasmita (2001) dan Puspitasari (2013) yang menyatakan bahwa usaha mikro kecil tradisional tidak memiliki orientasi pertumbuhan dan keinovatifan. Menurut Riyanti (2003), ada beberapa faktor yang dapat menghambat keberhasilan usaha antara lain (1) kurangnya kemampuan manajerial, (2) kurangnya pengalaman, (3) kekurangan modal, dan (4) ketidakmampuan menanggapi perubahan dan beradaptasi terhadap perubahan. Berdasarkan hasil penelitian, kurangnya kemampuan manajerial pengrajin tempe terlihat dari tidak adanya catatan pembukuan serta tidak adanya pemisahan keuangan keluarga dengan perusahaan.

ANALISIS PERILAKU KEWIRAUSAHAAN USAHA MIKRO KECIL PADA PENGRAJIN TEMPE DENGAN PENDEKATAN STRUCTURAL EQUATION MODELS (SEM)
Analisis pengukuran model merupakan tahap untuk memastikan bahwa konstruk yang digunakan pada penelitian ini memenuhi kriteria valid dan reliabel. Model pengukuran pada SEM adalah untuk mengukur hubungan keerataan antara variabel laten dengan variabel indikator (manifest). Nilai hubungan keeratan antar variabel tersebut dapat dilihat dari nilai loading factor-nya ( $\lambda$ ). Semakin besar nilai loading factor antar variabel manifest dengan variabel laten, maka menunjukkan hubungan yang semakin dekat atau erat antar variabel tersebut.

Nilai t-value di bawah 1,96 berarti loading factor tersebut tidak signifikan. Sementara nilai loading factor di bawah 0.3 dapat dihapuskan karena nilai batas dari loading factor standar adalah $<0,50$ (Igbaria et al dalam Wijanto 2008) atau $<0,70$ (Rigdon dan Ferguson dalam Wijanto 2008). Namun ada batas loading factor yang dapat ditoleransi yaitu $<0,50$ tetapi masih $\geq 0,30$ dapat dipertahankan ((Igbaria et al dalam Wijanto 2008). Model yang kurang baik perlu dilakukan respesifikasi untuk menghasilkan model terbaik dengan kriteria memenuhi goodness of fit. Berikut adalah model struktural perilaku kewirausahaan pada pengrajin tempe setelah respesifikasi dapat dilihat pada Gambar 3 dan 4.

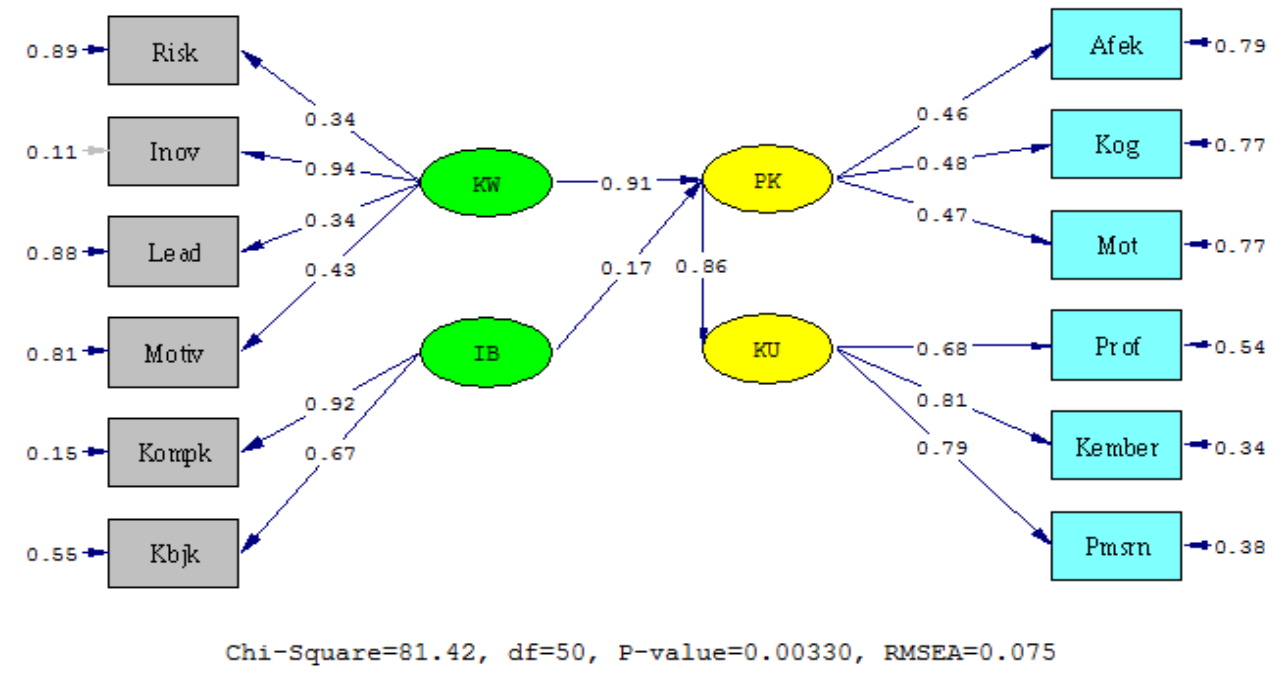

Gambar 3. Standardized Coeficient Model Structural Perilaku Kewirausahaan UMK Tempe 


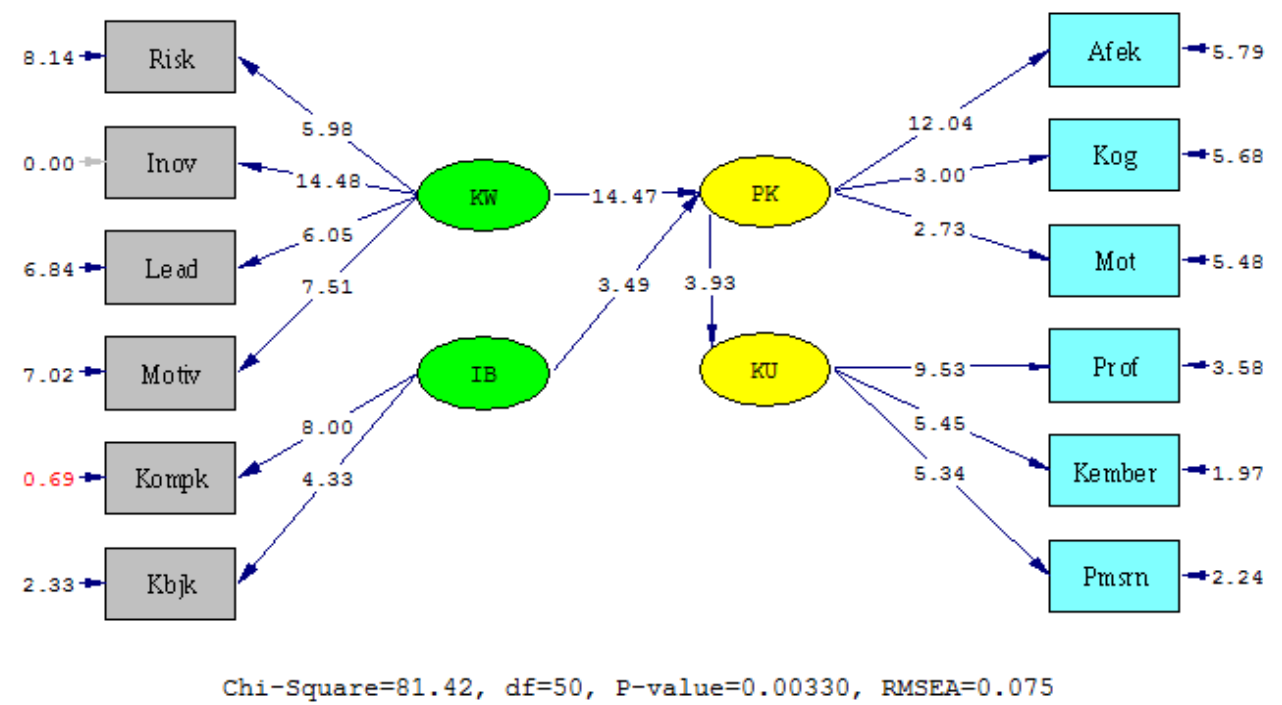

Gambar 4. T-value Model Structural Perilaku Kewirausahaan UMK Tempe

Setelah mendapatkan model terbaik hasil respesifikasi, maka dilakukan uji kecocokan keseluruhan model. Uji kecocokan model struktural secara keseluruhan dapat dilihat dari ukuran goodness of fit (GOF). Berikut adalah hasil uji kecocokan keseluruhan model setelah respesifikasi dengan dibandingkan uji kecocokan keseluruhan model sebelum respesifikasi (model awal) dapat dilihat pada Tabel 3.

\section{PENGARUH KARAKTERISTIK} WIRAUSAHA TERHADAP PERILAKU KEWIRAUSAHAAN USAHA MIKRO KECIL PADA PENGRAJIN TEMPE

Berdasarkan model yang telah direspesifikasi (good fit) pada penjelasan sebelumnya.
Jelas bahwa karakteristik wirausaha mempengaruhi secara langsung perilaku kewirausahaan. Pengaruh dari karakteristik wirausaha yang dijelaskan oleh variabel laten karakteristik wirausaha (KW) terhadap perilaku kewirausahaan (PK) pada pengrajin tempe sangat dominan, yaitu sebesar $(\gamma=$ 0,91) (Gambar 3). Berdasarkan nilai dari faktor loading tersebut terlihat bahwa karakteristik wirausaha mempengaruhi perilaku sangat kuat karena nilai faktor loadingnya yang besar. Variabel yang paling besar mencerminkan karakter wirausaha pada pengrajin tempe adalah inovatif $(\lambda=$ $0,94)$.

Tabel 3. Hasil Uji Kecocokan Model (Goodness of Fit Test)

\begin{tabular}{|l|c|c|c|c|c|c|}
\multirow{2}{*}{ Goodness of Fit } & & \multicolumn{3}{c|}{ Model Awal } & \multicolumn{2}{c|}{ Setelah Respesifikasi } \\
\cline { 2 - 7 } & Cutt off value & Hasil & Keterangan & Hasil & Keterangan \\
\hline $\begin{array}{l}\text { Significance Probability(P-value) } \\
\text { Chi square }\end{array}$ & $\leq 0.05$ & 0.000 & Good Fit & 0.0033 & Good Fit \\
\hline $\begin{array}{l}\text { Root Mean Square (RMR) } \\
\text { RMSEA(Root Mean square Error }\end{array}$ & $\begin{array}{c}\leq 0.05 \text { atau } \leq 0.1 \\
\leq 0.08\end{array}$ & 0.12 & Poor Fit & 0.089 & Good Fit \\
\hline $\begin{array}{l}\text { of Approximation) } \\
\text { AGFI(Adjusted Goodness of Fit }\end{array}$ & $\geq 0.90$ & 0.13 & Poor Fit & 0.075 & Good Fit \\
$\begin{array}{l}\text { Index) } \\
\text { GFI(Goodness of Fit) }\end{array}$ & $\geq 0.90$ & 0.87 & Marginal Fit & 0.92 & Good Fit \\
\hline $\begin{array}{l}\text { CFI (Comparative Fit Index) } \\
\text { Normed Fit Index (NFI) }\end{array}$ & $\geq 0.90$ & 1.00 & Good Fit & 0.96 & Good Fit \\
\hline
\end{tabular}


Karakteristik inovatif yang dilakukan oleh pengraijin tempe yaitu dengan melakukan inovasi pada produk, melakukan perubahan ukuran, membuat jenis tempe yang berkualitas super, atau membuat tempe dengan kemasan yang berbeda-beda. Selain inovasi pada produk, inovasi dilakukan juga pada peralatan yang digunakan, serta inovasi pada cara pemasaran. Tingginya karakteristik inovatif seorang wirausaha dapat menjadi cerminan bahwa inovasi diperlukan pada usaha pembuatan tempe pada penelitian ini. Mungkin secara langsung proses inovasi tidak terlihat secara nyata, namun inovasi ini tetap ada pada usaha pembuatan tempe. Pengrajin tempe yang berhasil dalam menjalankan usaha ini merupakan pengrajin yang memiliki karakteristik inovatif yang menjadi karakter seorang wirausaha. Dikarenakan dengan adanya karakteristik inovatif seseorang dapat menciptakan sesuatu yang berbeda, dan hal inilah kunci keberhasilan seorang wirausaha (Munandar 2009; Dwijanto 2006; Burhanuddin 2014; Bosma 2011)

\section{PENGARUH IKLIM BISNIS TERHADAP PERILAKU KEWIRAUSAHAAN USAHA MIKRO KECIL PADA PENGRAJIN TEMPE}

Pengaruh iklim bisnis yang dijelaskan oleh variabel laten iklim bisnis (IB) terhadap perilaku kewirausahaan berdasarkan Structural Equation Models yaitu sebesar ( $\gamma=$ $0,17)$, dan signifikan dengan nilai t-hitung sebesar 3,49. Faktor iklim bisnis yang mempengaruhi perilaku kewirausahaan dapat direfleksikan atau dicirikan oleh variabel kekompakan antar pengrajin tempe $(\lambda=0,92)$, kebijakan pemerintah $(\lambda=0,67)$. Kekompakan pengrajin tempe memberikan sumbangan yang tinggi terhadap iklim bisnis. Hal ini juga terbukti dengan adanya hasil wawancara, bahwa pengrajin tempe memang memiliki kekompakan yang baik. Sebagai contoh pada saat terjadinya kenaikan harga kedelai yang tinggi, para pengrajin tempe kompak melakukan demo kepada pemerintah untuk menurunkan harga kedelai. Tidak hanya itu kekompakan juga dapat dilihat bagaimana antar pengrajin tempe dalam menjalankan usaha, saling membantu selama proses produksi dengan cara berbagi peralatan produksi dengan bergantian. Kekompakan menunjukkan adanya kebersamaan antar pelaku usaha dalam memajukan usaha. Kekompakan antara pengrajin tempe di Bogor terbentuk karena adanya kesamaan asal daerah yaitu Pekalongan. Dengan adanya kesamaan asal usul maka secara tidak langsung budaya yang terbentuk pun sama. Kesamaan budaya inilah yang mempengaruhi kekompakan para pengrajin tempe untuk dapat saling bekerja sama dalam menjalankan usaha.

Sementara indikator iklim bisnis lain yang memberikan kontribusi adalah kebijakan pemerintah. Kebijakan pemerintah ini berkaitan dengan kebijakan penetapan harga input. Pengrajin tempe mengharapkan pemerintah dapat membuat harga kedelai stabil. Faktor loading dari kebijakan pemerintah yang memberikan kontribusi kepada iklim bisnis sebesar $(\lambda=0,67)$. Namun secara keseluruhan, variabel laten iklim bisnis memberikan pengaruh yang positif dan signifikan meskipun nilai loadingnya kecil. Hal ini dimungkinkan bahwa pengaruh iklim bisnis terhadap perilaku kewirausahaan tidak terlalu besar. Hal ini ditunjukkan dengan adanya keinginan dan motivasi yang kuat dari pengrajin tempe untuk tetap menjalankan usaha tanpa menyerah meskipun harga input meningkat.

Perilaku kewirausahaan dapat tumbuh dan berkembang meskipun membutuhkan waktu dan perlunya dukungan lingkungan yang kondusif, seperti bantuan dari pemerintah yang sesuai dengan kebutuhan dan tepat sasaran (Puspita, 2013). Bantuan dari lingkungan eksternal (iklim bisnis) dapat berupa dukungan dari pemerintah yang berupa jaminan ketersediaan input, dukungan modal, serta informasi pasar (lokasi pemasaran yang layak). Berdasarkan data dari penelitian, yang dibutuhkan oleh pengrajin tempe adalah kestabilan harga input. Sementara untuk ketersediaan input tidak menjadi masalah karena kedelai berasal 
impor dan selalu ada, namun yang menjadi masalah adalah harga yang diterima oleh pengrajin yang tinggi.

Kesuksesan suatu usaha tidak hanya ditentukan oleh satu faktor saja, tetapi terkait oleh beberapa faktor baik dari internal dan ekternal. Rente (2010) menyatakan bahwa faktor penentu keberhasilan UKM terdiri dari faktor internal dan eksternal. Faktor internal adalah faktor dari dalam usaha seperti sumber daya manusia, keuangan, serta proses produksi. Sementara faktor penentu sukses eksternal dapat berupa kebijakan pemerintah, situasi pasar, serta informasi pasar.

\section{PENGARUH PERILAKU \\ KEWIRAUSAHAAN TERHADAP KINERJA USAHA MIKRO KECIL PADA PENGRAJIN TEMPE}

Hasil analisis SEM pada hasil penelitian ini menunjukkan adanya hubungan perilaku kewirausahaan mempengaruhi kinerja usaha. Hubungan antara perilaku kewirausahaan dengan kinerja usaha sebesar $(\beta=0,86)$ signifikan dengan nilai t-hitung sebesar 3.93. Perilaku kewirausahaan merupakan variabel laten yang tidak dapat dilihat secara langsung pengaruhnya, tetapi melalui indikatorindikator yang mencirikan atau merefleksikan. Perilaku kewirausahaan direfleksikan oleh tiga variabel indikator yaitu afektif (sikap) $(\lambda=0,46)$, kognitif (pengetahuan) $(\lambda=0,48)$, serta motorik (keterampilan) $(\lambda=0,47)$. Kontribusi paling besar adalah kognitif (pengetahuan) yang dapat mencerminkan perilaku kewirausahaan pada pengrajin tempe.

Afektif (sikap) lebih kepada sikap yang dilakukan pengrajin tempe dalam menjalankan usaha, kedisiplinan (tepat waktu), kejujuran dalam penggunaan modal usaha, serta penggunaan bahan-bahan pada produk. Menurut Setiana (2005), afektif sebagai sikap seseorang terhadap gejala sosial yang dapat menyangkut banyak aspek yang berpengaruh terhadap perilaku suatu komunitas masyarakat. Tidak hanya sikap dan pengetahuan yang mencirikan perilaku wirausaha, seorang wirausaha harus memiliki keterampilan. Keterampilan (motorik) yang mencirikan perilaku wirausaha dilihat dari inovasi dan kreativitas yang dilakukan oleh pengrajin tempe. Perilaku kewirausahaan dipengaruhi oleh faktor yang ada pada individu itu sendiri yang menjadikan sebagai dorongan atau motivasi yang kemudian dicirikan oleh sikap dalam bertindak, pengetahuan dalam menjalankan usaha, serta keterampilan dalam menciptakan produk. Beberapa sifat yang terkait dengan perilaku wirausaha menurut Plotkin (Riyanti, 2003) yaitu adanya sifat kreatif, keingintahuan, keyakinan berhasil, serta kesabaran. Menurut Puspita (2013), perilaku kewirausahaan dapat ditumbuhkan dengan peningkatan motivasi dalam mencapai kesuksesan dalam menjalankan usaha. Dengan adanya motivasi yang kuat untuk sukses akan memunculkan ketekunan dan keberanian mengambil risiko dalam menjalankan usaha, sehingga meningkatkan keinginan untuk mendapatkan penghasilan yang lebih besar. Adanya perilaku kewirausahaan yang muncul pada diri seorang wirausaha akan berpengaruh terhadap kinerja usaha yang dijalankan.

Berdasarkan hasil analisis Structural Equation Models (SEM) dalam penelitian ini dapat dilihat faktor-faktor yang berpengaruh terhadap perilaku kewirausahaan serta kinerja usaha (Gambar 2). Oleh karena itu peningkatan perilaku kewirausahaan akan meningkatkan kinerja usaha pengrajin tempe. Hal ini dikuatkan oleh penelitian Dirlanudin (2010), serta Puspitasari (2013) yang menunjukkan bahwa perilaku kewirausahaan berpengaruh langsung terhadap keberhasilan usaha yaitu peningkatan keuntungan, peningkatan jumlah dan loyalitas pelanggan, peningkatan volume penjualan, peningkatan kualitas dan kuantitas produk, terjadinya diversifikasi produk, perluasan pemasaran, serta kemampuan bersaing. Berdasarkan penelitian ini, kinerja usaha dijelaskan oleh peningkatan keuntungan $(\lambda=0,68)$, kemampuan bersaing $(\lambda=0,81)$, serta pemasaran (perluasan wilayah pemasaran dan loyalitas pelanggan) dengan faktor loading $(\lambda)$ ),79.

Kemampuan bersaing menyumbangkan faktor loading terbesar pada kinerja usaha. 
Persaingan antar pengrajin tempe sangat tinggi, karena jumlah pengrajin tempe yang banyak dengan wilayah pemasaran yang tidak terlalu banyak. Kemampuan bersaing antar pengrajin tempe ditunjukkan dengan cara membuat tempe dengan kemasan yang beragam sesuai keinginan konsumen, menggunakan bahan baku yang aman untuk kesehatan, serta memberi merek pada produk yang dijual. Secara keseluruhan, perilaku kewirausahaan pada pengrajin tempe dipengaruhi paling besar oleh variabel karakteristik individu pengrajin, hal ini dilihat dari bagaimana para pengrajin tempe menjalankan usaha dengan didasari karakteristik yang kuat seperti kemauan dalam berinovasi, kemauan mengambil risiko, motivasi untuk sukses, serta kemampuan memimpin usaha.

Karakteristik tersebut yang membentuk perilaku wirausaha pengrajin tempe. Namun dalam membentuk perilaku tidak hanya dipengaruhi oleh satu faktor saja, ternyata faktor lingkungan yang pada penelitian ini adalah iklim bisnis memiliki pengaruh dalam membentuk perilaku wirausaha. Variabel yang dominan merefleksikan iklim bisnis pada usaha pembuatan tempe adalah kekompakan yang terjalin antara pengrajin tempe serta kebijakan yang dibuat oleh pemerintah yang berkaitan dengan regulasi usaha dalam penentuan input. Hal ini dikarenakan pada industri tempe input yang digunakan adalah kedelai impor sehingga peran pemerintah sangat diperlukan untuk menunjang keberhasilan usaha industri ini.

\section{SIMPULAN DAN SARAN}

\section{SIMPULAN}

Berdasarkan hasil penelitian ini dapat ditarik beberapa kesimpulan sebagai berikut:

1. Adanya karakteristik wirusaha pada pelaku usaha mikro kecil, dan semakin besar skala produksi maka karakteristik wirausahanya semakin kuat.

2. Karakteristik wirausaha dan iklim bisnis berpengaruh positif dan siginifikan terhadap perilaku kewirausahaan. Hal ini menunjukkan bahwa peningkatan inovasi, keberanian mengambil risiko, kepemimpinan, motivasi berwirausaha, kekompakan, serta kebijakan pemerintah dapat meningkatkan perilaku kewirausahaan.

3. Perilaku kewirausahaan berpengaruh positif dan signifikan terhadap kinerja usaha. Hasil ini menunjukkan bahwa, peningkatan perilaku kewirausahaan akan meningkatkan kinerja usaha pengrajin tempe

\section{SARAN}

Berdasarkan hasil penelitian ini diperoleh saran bagi pengrajin tempe maupun pemerintah dan pihak lain yang mendukung usaha ini agar dapat berkembang di masa yang akan datang yaitu:

1. Untuk meningkatkan keberhasilan usaha pembuatan tempe diperlukan keberanian dalam inovasi baik produk, teknologi, maupun pemasaran. Pengrajin tempe harus mampu mencari informasi dan peluang pasar untuk meluaskan pemasaran tempenya agar tidak hanya terfokus pada satu pasar, sehingga usahanya akan berkembang.

2. Perlu adanya dukungan pemerintah dalam penentuan harga kedelai impor yang digunakan sebagai bahan baku pembuatan tempe. Dengan adanya kestabilan harga kedelai dapat memicu motivasi pengrajin tempe untuk meningkatkan produksi.

3. Selain itu, perlu adanya pengaktifan kembali anggota koperasi tahu tempe Indonesia. Hal untuk mempermudah para pengrajin tempe dalam memperoleh input, memperoleh pelatihan dan penyuluhan mengenai pengembangan usaha dan pembuatan tempe dengan standar keamanan pangan yang baik. Hal ini sangat diperlukan untuk meningkatkan kreativitas dan inovasi guna peningkatan kualitas produk yang diproduksi. 
4. Penelitian ini memiliki keterbatasan pada ruang lingkupnya, perilaku kewirausahaan yang diteliti hanya pada sektor usaha mikro kecil pada pengrajin tempe di Bogor, Jawa Barat dan tidak dapat digeneralisasikan untuk usaha mikro kecil lainnya. Oleh karena itu, masih diperlukan penelitian lain mengenai perilaku kewirausahaan pada sektor usaha lainnya.

\section{DAFTAR PUSTAKA}

Alma B. 2010. Kewirausahaan Edisi Revisi. Bandung: Alfabeta

Bosma N, Wennekers S, Amorós JE. 2011. Extended Report: Entrepreneurs and Entrepreneurial Employees Across the Globe. London (GB): Global Entrepreneurship Research Association.

Burhanuddin. 2014. Pengaruh Aktivitas Kewirausahaan Peternakan Ayam Broiler Terhadap Pertumbuhan Ekonomi.Disertasi Doktor .Sekolah Pascasarjana, Institut Pertanian Bogor. Bogor.

Casson M, Yeung B, Basu A, Wadeson N. 2006. The Oxford Handbook of Entrepreneurship. New York : Oxford University Press Inc.

Delmar, F.1996. Entrepreneurial Behavior and Business Performance [Dissertation]. Stockholm : Ekonomiska Forknings Institute.

Dirlanudin. 2010. Perilaku Wirausaha dan Keberdayaan Pengusaha Kecil Industri Agro: Kasus di Kabupaten Serang Provinsi Banten [Disertasi]. Bogor : Institut Pertanian Bogor.

Dwijanto. 2006. Definisi Kreativitas Menurut Para Ahli. http:/ / definisiahli.blogspot.com [diunduh: 8 Mei 2015]

Fugate D,Kirk C, Heriot, and Raja B. 2005. Microenterprises in the Kingdom of Nepal:On the Path to Economic Development. Journal of Business.
Kellermanns FW, Floyd SW. 2008.An Exploratory Study of Family Member Characteristics and Involvement: Effects on Entrepreneurial Behavior in the Family Firm. In: Eds S.Family Business Review 2008.

Kementrian Koperasi dan UKM .2012. Jumlah Unit Usaha UMKM. www.depkop.go.id [diunduh: 8 Agustus 2014]

Mazzarol T,Volery $\mathrm{T}$, Doss $\mathrm{N}$, danThein $\mathrm{V}$. 1999. Factors influencing small business start-ups. International Journal of Entrepreneurial Behaviour and Research 5 (2): 48-63.

Meredith GG, RE Nelson, dan PA Nick. 1996. Kewirausahaan Teori dan Praktek. Dialih bahasakan oleh Andre Asparsayogi. Jakarta: Pustaka Binaman Pressindo

Munandar, Utami, 1999. Pengembangan Kreativitas Anak Berbakat. Jakarta: PT

Penerbit Rineka Cipta.

Praag CM. 2005. Successful Entrepreneurship. United Kingdom : Edward Elgar Publishing Limited.

Puspitasari. 2013. Pengaruh Perilaku Kewirausahaan Petani Anggrek Terhadap Kinerja Usaha : Kasus di Kecamatan Gunung Sindur dan Parung, Kabupaten Bogor, dan Kecamatan Serpong, Kota Tangerang Selatan [Tesis]. Bogor: Institut Pertanian Bogor.

Rente, Yohanes. 2010. Pengaruh Budaya Etnis dan Perilaku Kewirausahaan Terhadap Kinerja Usaha Mikro Kecil Agribisnis. Jurnal Manajemen dan Kewirausahaan, Vol. 12, No.2. September 2010: 133-141. Jakarta.

Riyanti BP .2003. Kewirausahaan Dari Sudut Pandang Psikologi Kepribadian. Jakarta : PT.Grasindo.

Sapar. 2006. Faktor-Faktor yang Berhubungan Dengan Perilaku Kewirausahaan Pedagang Kaki Lima [Tesis]. Bogor: Institut Pertanian Bogor. 
Seagal G, Borgia and Jerry S. 2005. The Motivation To Become An Entrepreneur International Journal of Entrepreneurial Behaviour \& Research Vol. 11 No. 1

Setiana, Lucie. 2005. Teknik Penyuluhan dan Pemberdayaan Masyarakat. Bogor : Ghalia Indonesia.

Shane S, Edwin AL, Christoper JC. 2003. Entrepreneurial Motivation, Human Resource Management Review 13, 257279.

Sumantri B. 2013. Pengaruh Jiwa Kewirausahaan Terhadap Kinerja Usaha Wirausaha Wanita pada Industri Pangan Rumahan Di Bogor [Tesis]. Bogor: Institut Pertanian Bogor.

Wijanto SH. 2008. Structural Equation Modelling dengan LISREL 8.8. Yogyakarta: Graha Ilmu. 
